\title{
Management of caesarean scar ectopic pregnancy: a case report
}

\author{
Smritee Virmani*, Pushpa Kaul
}

Department of Obstetrics and Gynecology, SJM Hospital, Noida, Uttar Pradesh, India

Received: 07 April 2020

Accepted: 29 April 2020

\section{*Correspondence:}

Dr. Smritee Virmani,

E-mail: smriteevirmani@yahoo.co.in

Copyright: (c) the author(s), publisher and licensee Medip Academy. This is an open-access article distributed under the terms of the Creative Commons Attribution Non-Commercial License, which permits unrestricted non-commercial use, distribution, and reproduction in any medium, provided the original work is properly cited.

\section{ABSTRACT}

Caesarean scar ectopic involves an abnormal implantation of the embryo within the myometrium of previous caesarean scar. It is a rare and serious entity involving maternal complication like abnormal placentation, hemorrhage or death due to uterine rupture. Authors present a case report of 32 years old female diagnosed as a case of caesarean scar ectopic pregnancy on TVS and MRI and managed conservatively by USG guided D and C.

Keywords: Caesarean scar ectopic, Magnetic resonance imaging, Transvaginal sonography, Uterine rupture

\section{INTRODUCTION}

Caesarean scar ectopic pregnancy (CSP) rarest of all ectopic pregnancies occurs when a pregnancy implants on a previous caesarean scar. Incidence estimated in overall caesarean delivery is $1 / 1800$ to $1 / 2500 .{ }^{1}$ With increase in number of caesarean deliveries the incidence of caesarean scar ectopic has increased. Early diagnosis can be done by using sonography which is important because a delay can lead to increased maternal morbidity and mortality. The genesis of CSP involves implantation into the myometrium through a microscopic tract or a dehiscence in the previous uterine scar. ${ }^{2}$ Management option includes dilatation and curettage, laparotomy or laparoscopy for excision of trophoblastic tissue, local and/or systemic administration of methotrexate, B/L hypogastric artery ligation with trophoblastic evacuation and selective uterine artery embolization combined with curettage and/or methotrexate administration. ${ }^{3-7}$ In this case report authors present a case of viable caesarean scar pregnancy managed by USG guided D and C.

\section{CASE REPORT}

A 32-year-old female presented to us in the OPD with history of 2 months amenorrhea with complaint of spotting $\mathrm{p} / \mathrm{v}$ on and off with occasional abdominal pain since 5 days. Her obstetric history revealed G3P2L2 with previous 2 caesarean deliveries. Her first caesarean was in view of fetal distress and $2^{\text {nd }}$ for PROM with scar tenderness.

Her general physical examination was normal. On per speculum examination minimal bleeding was present. On bimanual examination uterus was 6 weeks size, anteverted with bilateral fornices free and no tenderness. Routine blood investigations were normal. On admission beta Hcg levels were 57524.84 IU/L. TVS revealed single live pregnancy CRL $0.74 \mathrm{~cm}$ (6 weeks +4 days) with cardiac activity seen in lower uterine segment at the level of previous caesarean scar in anterior wall with marked thinning of overlying myometrium. Uterine fundus and cervical canal were normal in appearance. No adnexal abnormality was identified (Figure 1). MRI was done to confirm the diagnosis. It reported a $\mathrm{G}$ sac bulging through myometrium of lower uterine segment in the region of caesarean scar. The anterior myometrium was thinned out with no bladder wall invasion. The posterior aspect of $G$ sac extended into the endometrial cavity of lower uterine segment with no thinning of posterior myometrium.

Diagnosis of caesarean scar ectopic pregnancy was made. Decision of suction curettage under transabdominal USG guidance was taken. G sac was removed completely and 
follow up values of beta hcg on day $2,7,14,21$ were 14, 733, 3248, 280, <6IU/ L respectively.

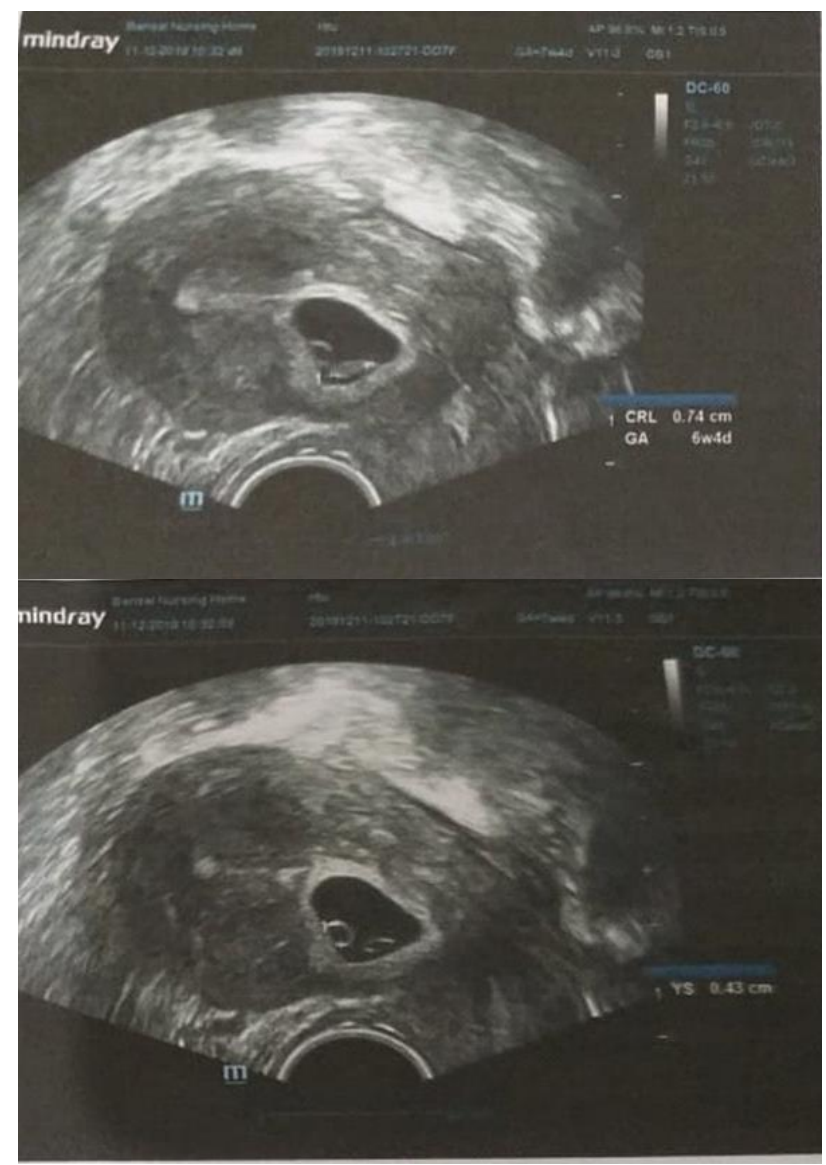

Figure 1: Caesarean scar ectopic pregnancy.

\section{DISCUSSION}

Implantation in the scar of a previous caesarean is thought to be the rarest of ectopic pregnancies. ${ }^{8}$ The risk in caesarean births has affected its incidence. It has been estimated that $6.1 \%$ of women with at least a previous caesarean and diagnosed as ectopic pregnancy will be caesarean scar pregnancy. ${ }^{9}$ Most women have a normal pregnancy following a CSP. Recurrence risk has been reported to be 3.2 to $5 \%$ in women with one previous CSP treated by D and C with or without uterine artery embolization. ${ }^{10}$ Factors associated with increased risk of recurrence include: lower uterine segment thickness less than $5 \mathrm{~mm}$, gestational sac bulging into the utero vesical fold and caesarean delivery in rural community hospital. ${ }^{4}$

The entity has diverse clinical presentations like minimal vaginal bleeding, abdominal discomfort, sometimes asymptomatic or may present with severe pain, substantial hemorrhage and collapse. In the present case patient presented with spotting $\mathrm{P} / \mathrm{V}$ with occasional abdominal pain. Early detection of CSP is of utmost importance to reduce serious complications related to it.
According to a recent review, following findings raise the suspicion level of this clinical entity

- Absence of fetal parts in the uterine cavity or cervical canal

- Development of the gestational sac in the anterior uterine wall at the isthmus (presumed site of the previous lower segment caesarean section scar)

- A thin myometrial layer between the bladder and gestational sac

- Triangular-shaped gestational sac

- Gestational sac that is close to the bladder and uterine wall

- Evidence of functional trophoblastic circulation on doppler examination, defined by the presence of an area of increased peri trophoblastic vascularity on colour doppler examination; or presentation of arteriovenous malformation in the area. ${ }^{5-7}$

MRI further provides crucial information where accurate diagnosis by USG is difficult. In this case patient TVS was suggestive of 6 weeks 4 days sac in the lower uterine segment at the level of previous caesarean scar in anterior wall with marked thinning of overlying myometrium. MRI was done to confirm the diagnosis. A number of management options are available which include D and $\mathrm{C}$, systemic methotrexate, local injection of methotrexate, uterine artery embolization, laparoscopic or hysteroscopic resection. ${ }^{11}$ This case was managed by USG guided D and $\mathrm{C}$ followed by serial evaluation of serum beta hcg on day $2,7,14$ and 21 .

\section{Funding: No funding sources Conflict of interest: None declared Ethical approval: Not required}

\section{REFERENCES}

1. Seow KM, Hwang JL, Tsai YL, Huang LW, Lin YH, Hsieh BC. Subsequent pregnancy outcome after conservative treatment of a previous cesarean scar pregnancy. Acta Obstet Gynecol Scand. 2004;83(12):1167-72.

2. Graesslin O, Dedecker F, Quereux C, Gabriel R. Conservative treatment of ectopic pregnancy in a cesarean scar. Obstet Gynecol. 2005;105(4):869-71.

3. Seow KM, Cheng WC, Chuang J, Lee C, Tsai YL, Hwang JL. Methotrexate for cesarean scar pregnancy after in vitro fertilization and embryo transfer. A case report. J Reprod Med. 2000;45(9):754-7.

4. Godin PA, Bassil S, Donnez J. An ectopic pregnancy developing in a previous caesarian section scar. Fertil Steril. 1997;67(2):398-400.

5. Persadie RJ, Fortier A, Stopps RG. Ectopic pregnancy in a caesarean scar: a case report. J Obstet Gynaecol Can. 2005;27(12):1102-6.

6. Sugawara J, Senoo M, Chisaka H, Yaegashi N, Tohoku OK. Successful conservative treatment of a 
cesarean scar pregnancy with uterine artery embolization. J Exp Med. 2005;206(3):261-5.

7. Yang MJ, Jeng MH. Combination of transarterial embolization of uterine arteries and conservative surgical treatment for pregnancy in a cesarean section scar: a report of 3 cases. J Reprod Med. 2003;48(3):213-6.

8. Herman A, Weinraub Z, Avrech O, Maymon R, RonEl R, Bukovsky Y. Follow up and outcome of isthmic pregnancy located in a previous caesarean section scar. $\mathrm{Br} \quad \mathrm{J}$ Obstet Gynaecol. 1995;102(10):839-41.

9. Zhang Y, Gu Y, Wang JM, Li Y. Analysis of cases with cesarean scar pregnancy. J Obstet Gynaecol Res. 2013;39(1):195-202.

10. McKenna DA, Poder L, Goldman M, Goldstein RB. Role of sonography in the recognition, assessment, and treatment of cesarean scar ectopic pregnancies. J Ultrasound Med. 2008;27(5):779-83.

11. Stevens EE, Ogburn P. Cesarean scar ectopic pregnancy: a case report of failed combination local and systemic methotrexate management requiring surgical intervention. J Reprod Med. 2011;56(78):356-8.

Cite this article as: Virmani S, Kaul P. Management of caesarean scar ectopic pregnancy: a case report. Int J Reprod Contracept Obstet Gynecol 2020;9:2646-8. 